International Journal of Engineering \& Technology, $7(3)(2018) 1420-1428$
International Journal of Engineering \& Technology
SPC
Website: www.sciencepubco.com/index.php/IJET
doi: $10.14419 /$ ijet. $v 73.14180$
Research paper

\title{
Optimization CFD study of erosion in 3D elbow during transportation of crude oil contaminated with sand particles
}

\author{
Rasha Hayder Al-Khayat ${ }^{1}$, Maher A. R. Sadiq Al-Baghdadi ${ }^{1}$, Ragad Aziz Neama ${ }^{1}$, Muhannad Al-Waily ${ }^{1}$ * \\ ${ }^{1}$ University of Kufa, Faculty of Engineering, Mechanical Engineering Department, Iraq \\ *Corresponding author E-mail: muhanedl.alwaeli@uokufa.edu.iq
}

\begin{abstract}
The oil industry transport the crude oil, but with entrained solid particles. Throughout the production operations of the upstream petroleum, crude oil as well as sand particles corroded from the zones of the formation are regularly conveyed through pipes as a mixture up to the well heads and among well heads and flow stations. In this study, a three-dimensional CFD (Computational fluid dynamics) model has been developed that describes a turbulent transport of solid sand particles as well as crude oil through elbows to predict the erosions rates, where various physical aspects have been combined together including flow turbulence, particle tracking, and erosion simulation. The model has been used to investigate the different parameters that effect for crude oil and sand particles on the erosive wear rate on the pipe walls. Where, the parametric studied for crude oil are viscosity, density, velocity and temperature, also, the parametric studied for sand particles are parti-cles size, particles density and mass flow rate. Therefore, the investigation included evaluated the erosive wear rate on the pipe walls with different parametric studding by using numerical method with CFD technique. This model includes simulation of the three dimensional for turbulent flow, sand particle, and erosion rates modeling. Where, used three methods to evaluating the erosive wear rate on the pipe walls, The Finite Model, The Erosion Rate (E/CRC) Model and The Erosion rate (DNV) Model. Also, in this work can be prediction of the ero-sion position occur on the pipe wall with various parametric effect. Then, the results presented shown that the rate of erosion is increase with increasing the friction between the oil and pipe wall by variable the parametric of crude oil or sand particles. Also, the results are shown that the position of erosion variable dependent on the parametric of oil and sand. Finally, the work shown that the CFD technique is good tool can be used to evaluating the erosion rate and erosion position on pipe wall with various crude oil and sand particles parametric.
\end{abstract}

Keywords: Crude Oi; Sand; Contamination; CFD; Erosion; Solid Particles; Elbow.

\section{Introduction}

Leakage from natural deposits is one of the major ways that crude oil affects the environment, [1]. During upstream petroleum production practices, sands from reservoirs are often transported up to the well heads and from the well heads to flow stations. The entrained sand may deposit on the walls of the elbow pipe due to pressure drop causing problems of erosive wear in the pipe elbow and then crude oil Leakage. The erosion is occur on the wall of pipe elbows due to the momentum of the sand particles, that carries them across the streamlines of the fluid and all of these particles impinge the pipe wall elbows. Therefore, the pipe system is failure due to it erosion occurred of the pipe elbow, which can be really dangerous and also expensive [2]. Thus, considerable concern in the oil industry is the erosion of pipe elbows due to sand, then, the materials erosion science is the major practical in the research and development applications on this problem.

Therefore, the materials engineering and the fluid dynamics science it's being addressed for the problem of erosion elbow, [3-5]. Then, must be evaluated by many methods to calculate the erosion rates values for a certain operating conditions set to avoid any errors from occurring. Thus, the investigation of erosion rate it's occurred in the pipe wall included prediction for the erosion position in the pipe wall everyplace erosion is expected to occur, in addition to the erosion rate for pipe wall. Due to, a lack of passable testing will be procedure the movement in developing an erosion-resistant pipe elbows is hampered, that would allow for fast assessment of erosion in unique flow path designs. Sand erosion phenomenon is highly complicated; therefore, many factors are contributed to the erosion rate. These parameters divided to the parameters of fluid flow effect, sand characterization effect and other parameters. The fluid flow parameters included flow rate, all properties of the fluid, as well as the sand parameters include sand rate, sand particles properties, and the other parameters effect are the equipment of the walls materials and/or the fitting equipment, and also the features of the geometries such as the shape as well as the size. Therefore, many methods have been development to combating the erosion rate occurs due to the sand particles. One of these methods is the CFD, it based erosion modeling is very powerful and can be applied to predict erosion in much complex engineering geometry [6], [7].

In this study, three-dimensional CFD model has been developed and used that describes a turbulent transport of solid sand particles as well as crude oil through elbows to predict the erosions rates under various transport parameters. This work allows us to examine more pipe design choices and "what if" scenarios than ever before. Moreover, crude oil flow modeling provides insights into our fluid flow problems that would be very expensive or simply unreasonable by experimental techniques alone. The additional 
insight and perception gained from the CFD simulation of the crude oil flow provides us confidence in our design, eschew the extra costs of over-specification, over-sizing, and decreasing risk.

\section{CFD modeling}

Three-dimensional CFD model of a turbulent transport of solid sand particles and crude oil through elbows to predict the erosions rates has been modeled, validated, detail presented, and discussed in detail by the current authors in their earlier work, [8]. In brief, the simulation model is built on the CFD technique and considers multi-component flow inside the crude oil flow elbows, [9-15]. The comprehensive simulation model includes: turbulent flow simulation, particle tracking, and erosion simulation.

\subsection{Computational domain}

As the numerical modelling of an entire elbow requires costly and powerful computing resources, not to mention the excessively long-time simulation needed; the investigated domain in the current simulation is focused on the three-dimensional section of the elbow only, Fig. 1.

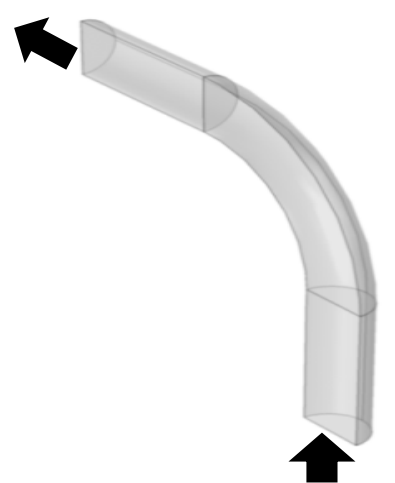

Fig. 1: Three Dimensional Computational Domain

\subsection{Modelling equations}

\subsubsection{The turbulence flow model}

A Newtonian and incompressible fluid having constant density is considered herein. The RANS forms of the momentum conservation as well as continuity equations are formulated as [8],

$\rho \frac{\partial \mathrm{U}}{\partial \mathrm{t}}+\rho \mathrm{U} \cdot \nabla \mathrm{U}+\nabla \cdot \overline{\left(\rho \mathrm{u}^{\prime} \otimes \mathrm{u}^{\prime}\right)}=-\nabla \mathrm{P}+\nabla \cdot \mu\left(\nabla \mathrm{U}+(\nabla \mathrm{U})^{\mathrm{T}}\right)+\mathrm{F}$

$\rho \nabla \cdot U=0$

Where U represents the mean velocity, while $\otimes$ stands for the outer vector product. In this work, the $\mathrm{k}-\omega$ model is carefully chosen over the model of $\mathrm{k}-\varepsilon$, due to its further accurate than the model of $\mathrm{k}-\varepsilon$ for flows connecting strong streamlines curvatures [8], where formulation of this turbulence model is as follows,

$\rho \frac{\partial \mathrm{k}}{\partial \mathrm{t}}+\rho \mathrm{u} \cdot \nabla \mathrm{k}=\left(\mathrm{P}_{\mathrm{k}}-\rho \beta^{*} \mathrm{k} \omega+\nabla \cdot\left(\left(\mu+\sigma^{*} \mu_{\mathrm{T}}\right) \nabla \mathrm{k}\right)\right)$

$\rho \frac{\partial \omega}{\partial \mathrm{t}}+\rho \mathrm{u} \cdot \nabla \omega=\left(\alpha \frac{\omega}{\mathrm{k}} \mathrm{P}_{\mathrm{k}}-\rho \beta \omega^{2}+\nabla \cdot\left(\left(\mu+\sigma \mu_{\mathrm{T}}\right) \nabla \omega\right)\right)$

Where,

$\mathrm{P}_{\mathrm{k}}=\mu_{\mathrm{T}}\left(\nabla \mathrm{u}:\left(\nabla \mathrm{u}+(\nabla \mathrm{u})^{\mathrm{T}}\right)-2 / 3^{*}(\nabla \cdot \mathrm{u})^{2}\right)-\frac{2}{3} \rho \mathrm{k} \nabla \cdot \mathrm{u}$

$\mu_{\mathrm{T}}=\rho \frac{\mathrm{k}}{\omega}, \alpha=\frac{13}{25}, \beta=\beta_{\mathrm{o}} \mathrm{f}_{\beta}, \beta^{*}=\beta_{\mathrm{o}}^{*} \mathrm{f}_{\beta}$

$\sigma=\frac{1}{2}, \sigma^{*}=\frac{1}{2}$ $\beta_{\mathrm{o}}=\frac{13}{125}, \mathrm{f}_{\beta}=\frac{1+70 \mathrm{X}_{\omega}}{1+80 \mathrm{X}_{\omega}}, \mathrm{X}_{\omega}=\left|\frac{\Omega_{\mathrm{ij}} \Omega_{\mathrm{jk}} \mathrm{S}_{\mathrm{ki}}}{\left(\beta_{\mathrm{o}}^{*} \omega\right)^{3}}\right|$

$\beta_{\mathrm{o}}^{*}=\frac{9}{100} \mathrm{f}_{\beta}^{*}=\left\{\begin{array}{c}1 \mathrm{X}_{\mathrm{k}} \leq 0 \\ \frac{1+680 \mathrm{X}_{\mathrm{k}}^{2}}{1+400 \mathrm{X}_{\mathrm{k}}^{2}} X_{\mathrm{k}}>0\end{array}\right.$, for, $\mathrm{X}_{\mathrm{k}}=\frac{1}{\omega^{3}}(\nabla \mathrm{k} \cdot \nabla \omega)$

Where $\omega_{i j}$ represents the mean tensor of rotation rate.

$\Omega_{\mathrm{ij}}=\frac{1}{2}\left(\frac{\overline{\partial \mathrm{u}_{1}}}{\partial \mathrm{x}_{\mathrm{j}}}-\frac{\overline{\partial \mathrm{u}_{\mathrm{j}}}}{\partial \mathrm{x}_{\mathrm{i}}}\right)$

And, $\mathrm{S}_{\mathrm{ij}}$ is the mean strain rate tensor,

$\mathrm{S}_{\mathrm{ij}}=\frac{1}{2}\left(\frac{\overline{\partial \mathrm{u}_{1}}}{\partial \mathrm{x}_{\mathrm{j}}}-\frac{\overline{\partial \mathrm{u}_{\mathrm{j}}}}{\partial \mathrm{x}_{\mathrm{i}}}\right)$

\subsubsection{Particle motion in a fluid model}

According to Newton's second law, the particle momentum can be formulated as [8]

$\frac{d}{d t}\left(m_{p} V\right)=F_{D}+F_{g}+F_{e x t}$

Where, $\mathrm{m}_{\mathrm{p}}$ refers to the mass of the solid particles in $\mathrm{kg}, \mathrm{v}$ is the velocity of the solid particle in $\mathrm{m} / \mathrm{s}, \mathrm{F}_{\mathrm{D}}$ stands for the drag force in $\mathrm{N}, \mathrm{F}_{\mathrm{g}}$ is the vector of gravitational force in $\mathrm{N}$, and $\mathrm{F}_{\text {ext }}$ represents any other external source in $\mathrm{N}$.

The drag force $\left(\mathrm{F}_{\mathrm{D}}\right)$ can be computed as,

$\mathrm{F}_{D}=\left(\frac{1}{\tau_{p}}\right) m_{p}(\mathrm{u}-\mathrm{v})$

Where $\tau_{p}$ is the response time of particle velocity in sec, $u$ stands for the flow velocity in $\mathrm{m} / \mathrm{s}$.

The instantaneous flow velocity presented in the drag force of the term of the turbulent dispersion is rewritten as,

$\mathrm{u}=\mathrm{U}+\mathrm{u}^{\prime}$

Where $\mathrm{U}$ is the time mean velocity while $\mathrm{u}$ ' is a turbulent fluctuation velocity, which is written as,

$\mathrm{u}^{\prime}=\varphi \sqrt{\frac{2 k}{3}}$

Where $\mathrm{k}$ is define as the turbulent kinetic energy, while $\varphi$ is define as a normally distributed random number with zero mean and unit standard deviation. The gravitational force is formulated as,

$\mathrm{F}_{g}=m_{p} \mathrm{~g} \frac{\left(\rho_{p}-\rho\right)}{\rho_{p}}$

Where $\rho_{p}$ represents the particle density in $\mathrm{kg} / \mathrm{m} 3, \rho$ stands for the surrounding fluid density in $\mathrm{kg} / \mathrm{m} 3$, while $\mathrm{g}$ is the gravitational direction.

\subsubsection{Erosion models}

The Erosion feature calculates the rate of erosive wear or the total mass removed per unit area due to the impact of particles at a boundary. The following three models have been modelled, [4-7].

i) The finite model

Finnie defined the volume removed from a surface as,

$V=\frac{c M U^{2}}{4 p\left(1+\frac{m r^{2}}{I}\right)}\left[(\cos \alpha)^{2}\right], \tan \alpha>\frac{P}{2}$

$V=\frac{c M U^{2}}{4 p\left(1+\frac{m r^{2}}{I}\right)} \frac{2}{P}\left[(\sin 2 \alpha)-2 \frac{(\sin \alpha)^{2}}{P}\right], \tan \alpha \leq \frac{P}{2}$ 
Where the parameters are defined as following,

$\mathrm{c}$ (dimensionless) is the fraction of particles cutting in an idealized manner.

$\mathrm{M}[\mathrm{kg}]$ is the total mass of eroding particles.

$\mathrm{U}[\mathrm{m} / \mathrm{s}]$ is the magnitude of the incident particle velocity.

$\mathrm{p}[\mathrm{Pa}]$ is the material Vickers hardness.

$\mathrm{m}[\mathrm{kg}]$ is the mass of an individual particle hitting the surface.

$\mathrm{r}[\mathrm{m}]$ is the average particle radius.

I [kg-m2] is the moment of inertia of an individual particle about its center of mass. For an isotropic sphere, $\mathrm{I}=2 \mathrm{mr} 2 / 5$.

$\alpha[\mathrm{rad}]$ is the angle of incidence, with $\alpha=0$ tangent to the surface and $\alpha=\pi / 2$ normal to the surface.

$\mathrm{P}$ is a dimensionless parameter, defined as $\mathrm{P}=\mathrm{K} /(1+\mathrm{mr} 2 / \mathrm{I})$, where $\mathrm{K}$ (dimensionless) is the ratio of vertical and horizontal forces acting on the particle.

In the Finnie model, particles are assumed to remove mass from the surface via an idealized cutting mechanism. It does not predict any erosive wear by particles at normal incidence to a surface, and is recommended for modeling erosion of ductile materials by particles at small angles of incidence.

ii) The erosion rate $(\mathrm{E} / \mathrm{CRC})$ model

The E/CRC model defines the erosion rate in terms of the ratio of mass lost by the surface to mass of incident particles,

$$
\begin{aligned}
& E=C F_{S}(B H)^{-0.59}\left(\frac{v}{1[m / s]}\right)^{n} F(\alpha) \\
& F(\alpha)=\left(5.40 \alpha-10.11 \alpha^{2}+10.93 \alpha^{3}-6.33 \alpha^{4}+1.42 \alpha^{5}\right)
\end{aligned}
$$

Where $\mathrm{C}$ is a dimensionless model coefficient, $F_{S}$ is the particle shape coefficient (dimensionless), and $\mathrm{BH}$ is the Brinell hardness of the wall material (dimensionless). The angle of incidence $\alpha$ is measured in radians.

iii) The erosion rate (DNV) model

The DNV model defines the erosion rate in terms of the ratio of mass lost by the surface to mass of incident particles,

$$
\begin{aligned}
& E=K\left(\frac{v}{1[m / s]}\right)^{-n} F(\alpha) \\
& F(\alpha)=\left(\begin{array}{c}
9.370 \alpha-42.295 \alpha^{2}+110.864 \alpha^{3}-175.804 \alpha^{4}+ \\
170.137 \alpha^{5}-98.398 \alpha^{6}+31.211 \alpha^{7}-4.170 \alpha^{8}
\end{array}\right)
\end{aligned}
$$

Where, $\mathrm{K}$ and $\mathrm{n}$ are constants that depend on the surface material.

\subsection{The grid used}

The finite-volume method was used to discretize the governing equations, which are in turn solved using a commercial CFD code having the power to address multi-physics problems. Grid sensitivity has been performed to ensure that the solutions acquired using the selected mesh is independent of the grid size. The selected grid consists of 44772 domain elements in total, 8908 boundary elements, and 590 edge elements, which was found to provide sufficient spatial resolution, Fig. 2. An iterative solution for the coupled equations was followed, where an error criterion of $1.0 \times 10^{-6}$ was considered sufficient enough to achieve the solution convergence. The solution was considered to be convergent when the relative error was less than in each field between two consecutive iterations. The initial and boundary conditions, the erosion prediction procedure in this work is a comprehensive procedure that based on a three-dimensional CFD technique, which has three most important steps: the turbulent fluid flow modeling, the solid particles tracking, and the erosion rates and the position prediction. The flow initial and boundary conditions have been listed in Table 1, [16-18].

\begin{tabular}{|c|c|c|}
\hline Parameter & & Value \\
\hline Temperature & & $298.15 \mathrm{~K}$ \\
\hline Carrier fluid & & Crude oil \\
\hline Nominal velocity & & $0.3 \mathrm{~m} / \mathrm{s}$ \\
\hline Sand diameter & & 170 microns \\
\hline Sand density & & $2200 \mathrm{~kg} / \mathrm{m}^{3}$ \\
\hline Mass flow rate of sand & & $0.6 \mathrm{~kg} / \mathrm{h}$ \\
\hline Oil viscosity & & $8 \mathrm{mPa} . \mathrm{s}$ \\
\hline Oil density & & $850 \mathrm{k} / \mathrm{m}^{3}$ \\
\hline Pipe diameter & & $0.2 \mathrm{~m}$ \\
\hline \multirow{3}{*}{ Pipe material (Iron) } & Modulus of Elasticity & $200 \mathrm{GPa}$ \\
\hline & Poisson ratio & 0.29 \\
\hline & Density & $7870 \mathrm{~kg} / \mathrm{m}^{3}$ \\
\hline
\end{tabular}

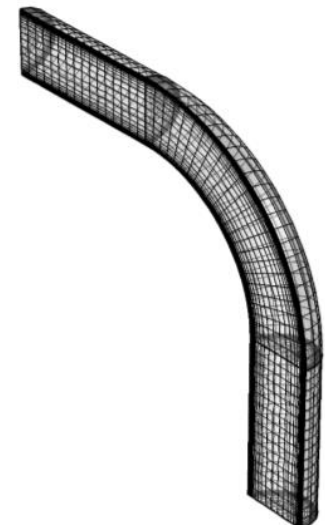

Fig. 2: Three Dimensional Computational Mesh of the Domain.

Table 1: Base Case Flow Conditions Used in the Model.

\section{Results and discussion}

The results presenting in this paper included evaluating the erosion of pipe wall by using numerical technique. Where, the numerical techniques is a good technique can be used to evaluating the results with a good agreement by comparison with other techniques, as present by many researches, [19-45].

The erosion prediction procedure in this work is a comprehensive procedure that based on a three-dimensional CFD technique, which has three main steps: turbulent fluid flow modeling, solid particles tracking, and erosion rates prediction. Therefore, the turbulent fluid flow modeling and the solid particles tracking are presented as in [8], and the erosion rates and the position prediction are presenting in this work, where, Figures. 3-9 show the erosion happens in pipe elbow during flow a contaminated crude oil with sand particles under various transport parameters. Where, the figures shown two parts of different parametric effect on the erosive wear on the pipe walls, the first effect of crude oil parametric, and second, the sand particles parametric, as,

i) Crude oil parametric effect, included the flowing,

1) Effect of crude oil viscosity on the erosive wear rate on the pipe walls, as shown in Fig. 3.

2) Effect of crude oil density on the erosive wear rate on the pipe walls, as shown in Fig. 4.

3) Effect of crude oil velocity on the erosive wear rate on the pipe walls, as shown in Fig. 5.

4) Effect of crude oil temperature on the erosive wear rate on the pipe walls, as shown in Fig. 6.

ii) Sand particles parametric effect, included the flowing,

1) Effect of sand particles size on the erosive wear rate on the pipe walls, as shown in Fig. 7.

2) Effect of the sand particles density on the erosive wear rate on the pipe walls, as shown in Fig. 8 .

3) Effect of the mass flow rate of sand on the erosive wear rate on the pipe walls, as shown in Fig. 9.

Where, the parametric values investigation in the model are presented in Table 2. 
Table 2: Range for Flow Conditions Used in the Model

\begin{tabular}{ll}
\hline Parameter & Value \\
\hline \multirow{3}{*}{ Temperature } & $275.15 \mathrm{~K}$ \\
& $298.15 \mathrm{~K}$ \\
& $323.15 \mathrm{~K}$ \\
Nominal velocity & $0.2 \mathrm{~m} / \mathrm{s}$ \\
& $0.3 \mathrm{~m} / \mathrm{s}$ \\
& $0.4 \mathrm{~m} / \mathrm{s}$ \\
Sand diameter & $120 \mathrm{microns}$ \\
& $170 \mathrm{microns}$ \\
Sand density & $220 \mathrm{microns}$ \\
& $1400 \mathrm{~kg} / \mathrm{m}^{3}$ \\
& $2200 \mathrm{~kg} / \mathrm{m}^{3}$ \\
Mass flow rate of sand & $3000 \mathrm{~kg} / \mathrm{m}^{3}$ \\
& $0.3 \mathrm{~kg} / \mathrm{h}$ \\
Oil viscosity & $0.6 \mathrm{~kg} / \mathrm{h}$ \\
& $0.9 \mathrm{~kg} / \mathrm{h}$ \\
& $1 \mathrm{mPa} . \mathrm{s}$ \\
Oil density & $8 \mathrm{mPa} . \mathrm{s}$ \\
& $20 \mathrm{mPa} . \mathrm{s}$ \\
& $750 \mathrm{~kg} / \mathrm{m}^{3}$ \\
& $850 \mathrm{~kg} / \mathrm{m}^{3}$ \\
\end{tabular}

Therefore, from the part one effects, shown in Figs. 3 to 6, can be shown the effect of crude oil on the erosive wear rate on the pipe walls as, Fig. 3 can be show the erosive wear rate on the pipe walls is decrease with increasing the crude oil viscosity, where, the rate of erosive wear decrease about $100 \%$ with increasing the viscosity from $1 \mathrm{mPa}$.s to $20 \mathrm{mPa}$.s. But, the Fig. 4 shown the erosive wear rate on the pipe walls is non-affected by change in crude oil density, where, the density of crude oil is changing from 750 to $950 \mathrm{~kg} / \mathrm{m} 3$.

Also, in Fig. 5 can be shown that the erosive wear rate on the pipe walls is increase with increasing the velocity of crude oil, where, the rate of erosive wear is increasing with about $95 \%$, when increasing the velocity of crude oil from $0.2 \mathrm{~m} / \mathrm{s}$ to $0.4 \mathrm{~m} / \mathrm{s}$. finally, from Fig. 6 can be shown the erosive wear rate on the pipe walls is non-affected by change in crude oil temperature, where the temperature is changed from $275.15 K^{o}$ to $323.15 K^{o}$. Also, in the effect of parametric was shown in part two, Figs. 7 to 9 can be shown the following effect of the sand particles on the erosive wear rate on the pipe walls, as, Fig. 7 shows that the erosive wear rate on the pipe walls is increase with increasing of sand particles size, where the rate of erosive wear is increase with $95 \%$ when increasing the sand particles size from 120 microns to 220 microns. Also, in Fig. 8 can be shown the erosive wear rate on the pipe walls is increase with increasing of sand particles density, where the rate of erosive wear increase about $85 \%$ when increase the sand particles density from $1400 \mathrm{~kg} / \mathrm{m} 3$ to $3000 \mathrm{~kg} / \mathrm{m} 3$. Finally, from Fig. 9 can be shown the effect of mass flow rate of sand on the erosive wear rate on the pipe walls, where, from the figure shown that the erosive wear rate is non-affected by change in the mass flow rate of sand, where, the flow rate of sand changes from $0.3 \mathrm{~kg} / \mathrm{h}$ to $0.9 \mathrm{~kg} / \mathrm{h}$.

The causes of increased or decreased rate of erosive wear on the pipe walls is due to increased friction between the oil or sand and the pipe walls, therefore, the effect of parametric on the rate of erosive wear were shown in Figs. 3 to 9 due to increasing or decreasing the friction. Also, can be shows from the figures that the erosion positions on the walls pipe are not fixed at same location with change of the parametric studied. Where, the erosion position is variable dependent on the effect of trajectories transport through the pipe elbow, it depended on the parametric effect, where the trajectories transport through the pipe elbow is presented in [8].

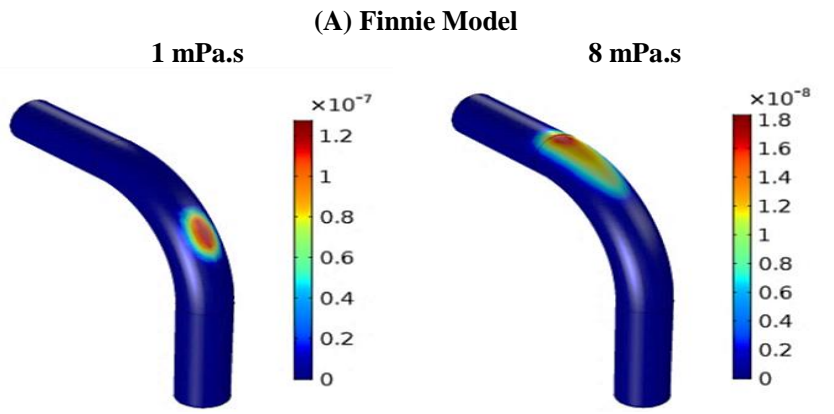

20 mPa.s

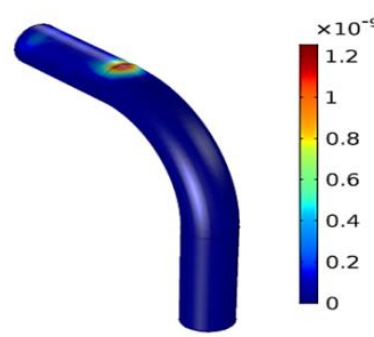

(B) DNV Model

$1 \mathrm{mPa} . \mathrm{s}$

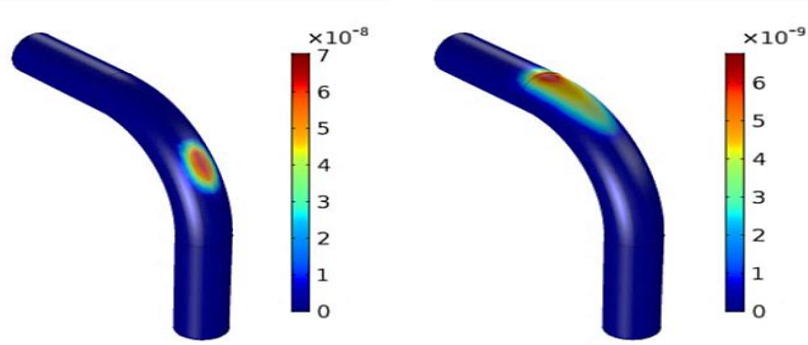

20 mPa.s
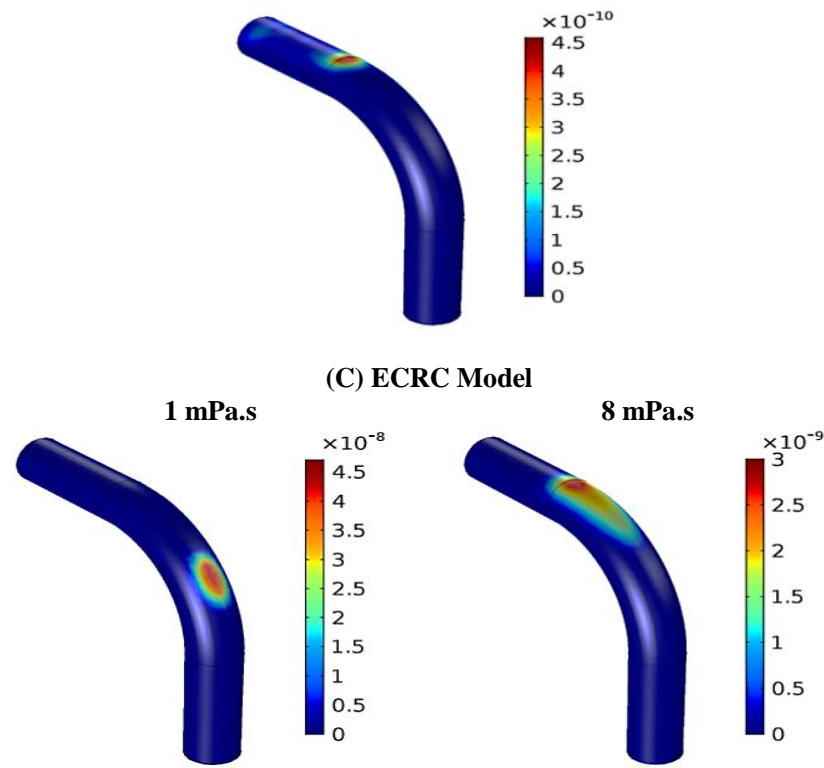

20 mPa.s

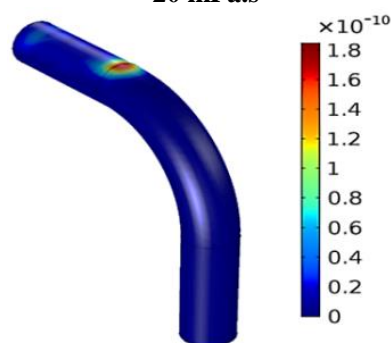

Fig. 3: Erosive Wear Rate $\left[\mathrm{Kg} / \mathrm{m}^{2}\right.$.s] for Different Values Fluid Viscosity. 

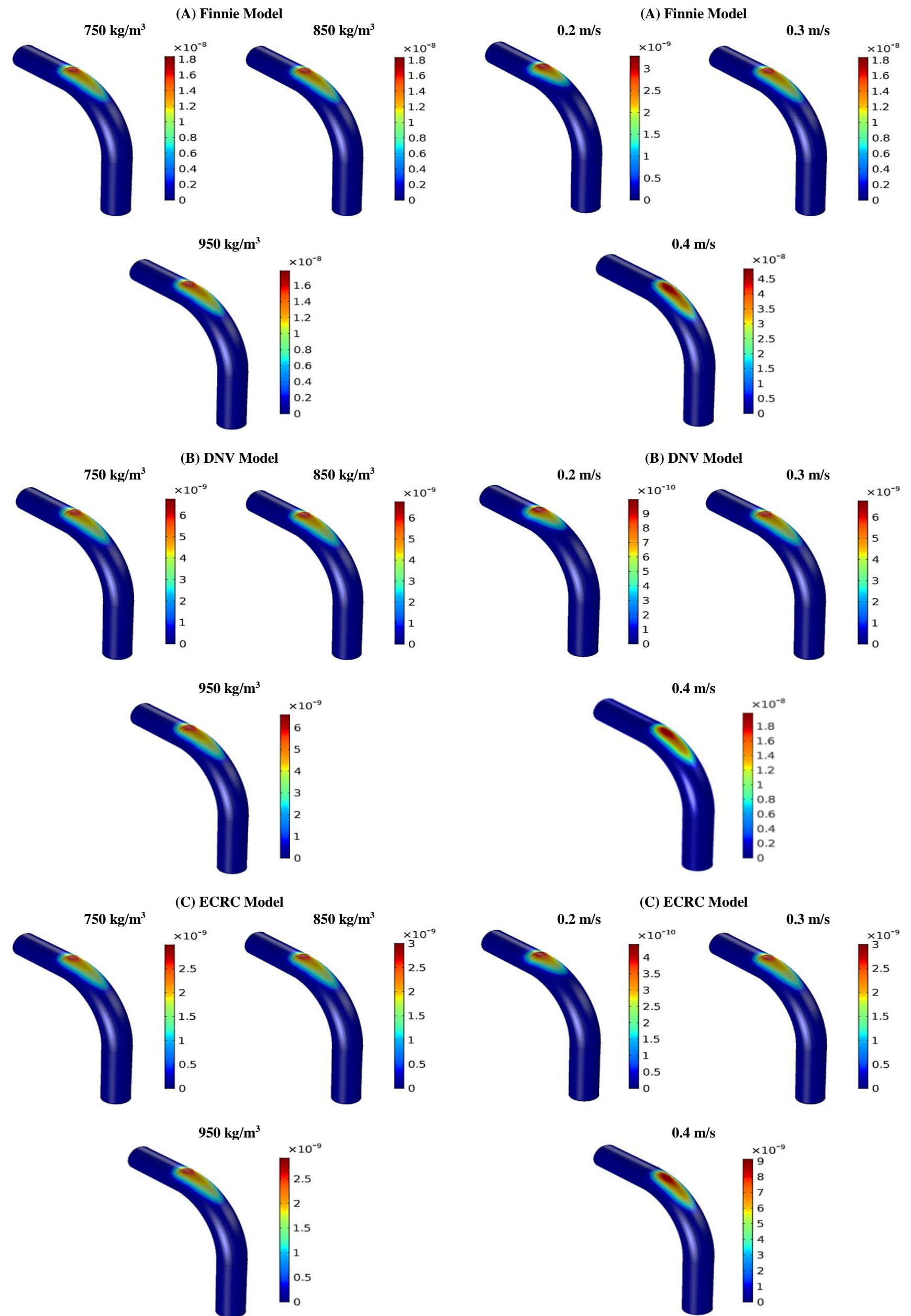

Fig. 4: Erosive Wear Rate $\left[\mathrm{Kg} / \mathrm{m}^{2} . s\right]$ for Different Values Fluid Density.

Fig. 5: Erosive Wear Rate $\left[\mathrm{Kg} / \mathrm{m}^{2} . \mathrm{s}\right]$ for Different Values Fluid Velocity. 

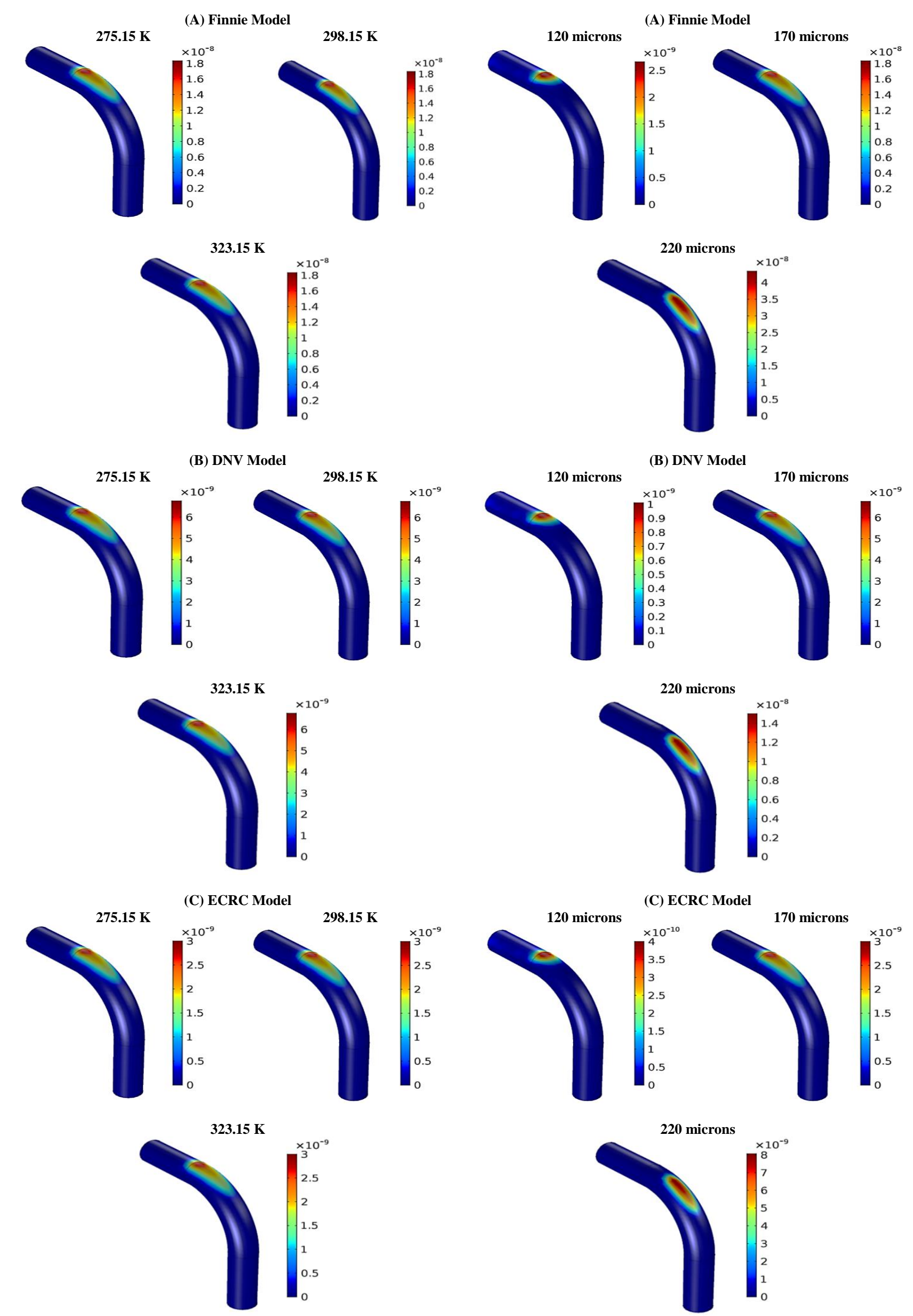

Fig. 6: Erosive Wear Rate $\left[\mathrm{Kg} / \mathrm{m}^{2} . \mathrm{s}\right]$ for Different Fluid Temperature.

Fig. 7: Erosive Wear Rate $\left[\mathrm{Kg} / \mathrm{m}^{2} . \mathrm{s}\right]$ for Different Sand Particles Size. 

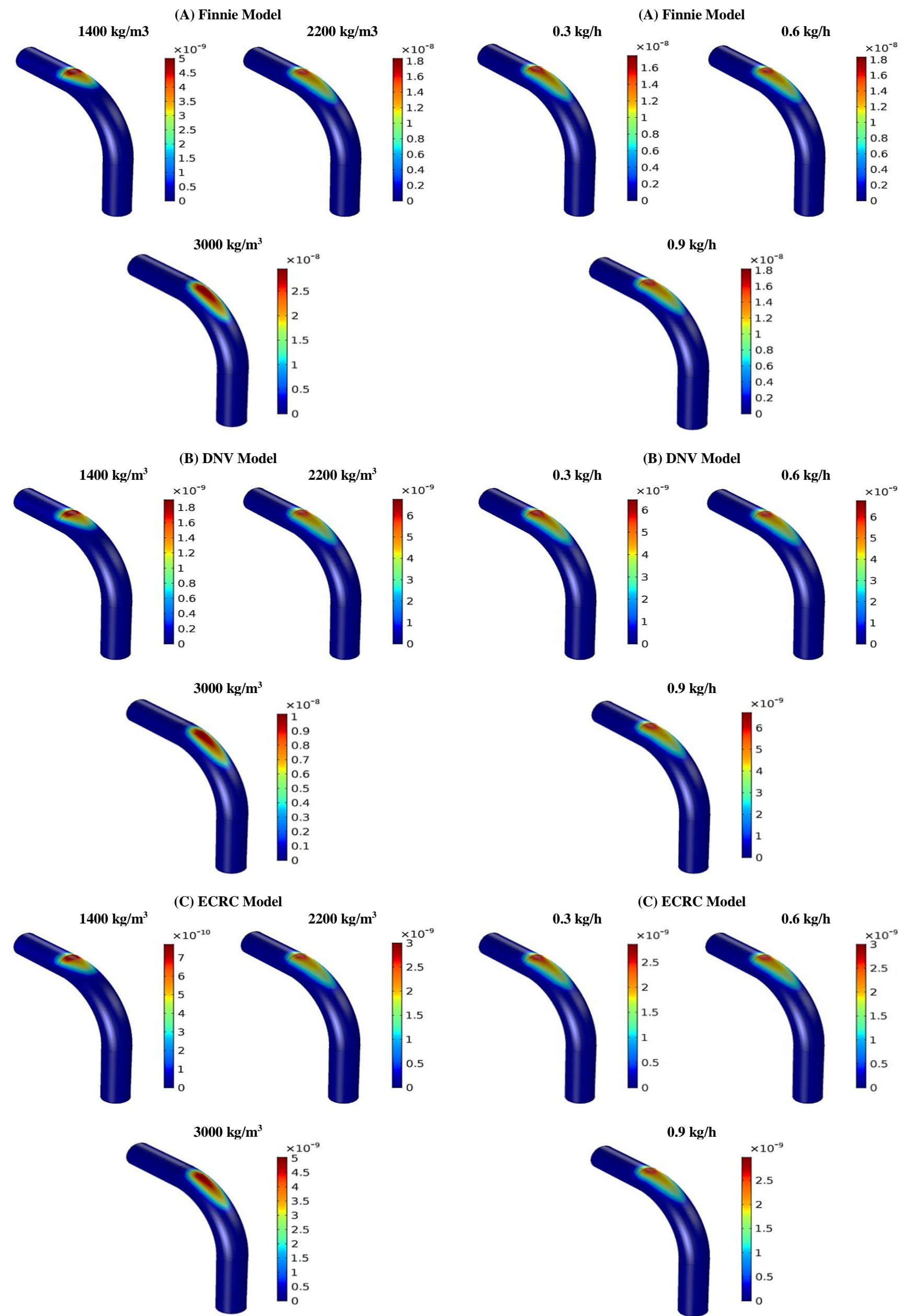

Fig. 8: Erosive Wear Rate $\left[\mathrm{Kg} / \mathrm{m}^{2} . \mathrm{s}\right]$ for Different Sand Particles Density.

Fig. 9: Erosive Wear Rate $\left[\mathrm{Kg} / \mathrm{m}^{2} . \mathrm{s}\right]$ for Different Mass Flow Rate of Sand. 


\section{Conclusion}

The research included evaluated the rate erosion and position erosion on pipe wall with different parametric of oil and sand particles effect with using of CFD technique of three erosion models, therefore, can be conclusion the flowing point from presented investigation, as,

1) The CFD technique is a powerful tool to evaluate the rate erosion and position erosion on pipe wall with different parameters include crude oil flow rate. Thus three-dimensional CFD model has been developed that describes the turbulent transport of the sand particles and the crude oil through elbows to simulate the erosions rates under various transport parameters.

2) The model is shown to be able to understand the many interacting, complex and transport phenomena that cannot be studied experimentally. There, the analysis offers valuable physical insight towards serve this model as an alternative sand management tool, and can be used to quantify oil recovery.

3) The erosion is increase with increasing the friction between the oil and pipe wall with variable the parameter affected on viscosity of oil flow through the pipe.

4) The position of the erosive wear on the pipe walls is variable with various the oil viscosity, oil velocity, sand particles size and sand particles density. But, the position of the erosive wear on the pipe walls is not variable with various the oil density, oil temperature and mass flow rate of sand. Where, the variable of wear occur as, the erosive wear rate on the pipe walls is increase with decreasing the oil viscosity, velocity crude oil, sand particles size, and sand particles density. But, the rate of the erosive wear is non-affected by change in oil density, oil temperature and the mass flow rate of sand.

5) The three models used were given the erosive wear for pipe with various fluid and sand particle parametric effect, thus, its models given different results of the wear. Then, for evaluating of the true value must be using the Two convergent values, its calculated by models.

\section{Acknowledgement}

The authors would like to express thanks for the Mechanical Engineering Department, Faculty of Engineering at University of Kufa, Kufa, Najaf, Iraq.

\section{References}

[1] Rajab M. Abousnina, Allan Manalo, Weena Lokuge, Jim Shiau, "Oil Contaminated Sand: An Emerging and Sustainable Construction Material", International Conference on Sustainable Design, Engineering and Construction, Procedia Engineering, Vol. 118, pp. 1119-1126, 2015.

[2] Lekan Taofeek Popoola, Alhaji Shehu Grema, Ganiyu Kayode Latinwo, Babagana Gutti, Adebori Saheed Balogun, "Corrosion problems during oil and gas production and its mitigation", International Journal of Industrial Chemistry, Vol. 35, pp. 1-15, 2013.

[3] Samuel Eshorame Sanni, A. S. Olawale, S. S. Adefila, "Modeling of Sand and Crude Oil Flow in Horizontal Pipes during Crude Oil Transportation", Journal of Engineering, pp. 1-7, 2015.

[4] Y. Zhang, E.P. Reuterfors, B.S. McLaury, S.A. Shirazi, E.F. Rybicki, "Comparison of Computed and Measured Particle Velocities and Erosion in Water and Air Flows", Wear Journal, Vol. 263, pp. 330-338, 2007. https://doi.org/10.1016/j.wear.2006.12.048.

[5] Xianghui Chena, Brenton S. McLaury, Siamack A. Shirazi, "Numerical and Experimental Investigation of the Relative Erosion Severity between Plugged Tees and Elbows in Dilute Gas/Solid TwoPhase Flow", Wear Journal, Vol. 261, pp. 715-729, 2006. https://doi.org/10.1016/j.wear.2006.01.022.

[6] Xianghui Chen, Brenton S. McLaury, Siamack A. Shirazi, "Application and Experimental Validation of a Computational Fluid Dynamics (CFD)-Based Erosion Prediction Model in Elbows and
Plugged Tees", Computers \& Fluids, Vol. 33, pp. 1251-1272, 2004. https://doi.org/10.1016/j.compfluid.2004.02.003.

[7] M. Atkinson, E.V. Stepanov, D.P. Goulet, S.V. Sherikar, J. Hunter, "High Pressure Testing sand Erosion in 3D Flow Channels and Correlation with CFD”, Wear Journal, Vol. 263, pp. 270-277, 2007. https://doi.org/10.1016/j.wear.2007.01.100.

[8] Maher A.R. Sasiq Al-Baghdadi, Kadhim Kamil Resan, Muhannad Al-Waily, "CFD Investigation of the Erosion Severity in 3D Flow Elbow During Crude Oil Contaminated Sand Transportation", The 1st International Scientific Conference of Nanotechnology and Advanced Materials in Petroleum \& Gas Industry, 3-4 May, University of Technology, Baghdad, Iraq, 2017.

[9] Maher A.R. Sadiq Al-Baghdadi, "A CFD study of hygro-thermal stresses distribution in PEM fuel cell during regular cell operation", Renewable Energy, Vol. 34, 03, pp. 674-682, 2009. https://doi.org/10.1016/j.renene.2008.05.023.

[10] Maher A.R. Sadiq Al-Baghdadi, "Performance comparison between airflow-channel and ambient air-breathing PEM fuel cells using three-dimensional computational fluid dynamics models", Renewable Energy, Vol. 34, No. 07, pp. 1812-1824, 2009. https://doi.org/10.1016/j.renene.2008.12.002.

[11] Maher A.R. Sadiq Al-Baghdadi, "Three-dimensional computational fluid dynamics model of a tubular-shaped PEM fuel cell", Renewable Energy, Vol. 33, No. 06, pp. 1334-1345, 2008. https://doi.org/10.1016/j.renene.2007.06.020.

[12] Maher A.R. Sadiq Al-Baghdadi "Studying the effect of material parameters on cell performance of tubular-shaped PEM fuel cell", Energy Conversion and Management, Vol. 49, No. 11, 2008.

[13] Maher A.R. Sadiq Al-Baghdadi, "Performance comparison between planar and tubular-shaped ambient air-breathing polymer electrolyte membrane fuel cells using three-dimensional computational fluid dynamics models", Journal of Renewable and Sustainable Energy, Vol. 01, No. 02, 2009.

[14] Maher A. R. Sadiq Al-Baghdadi, "Prediction of Deformation and Hygro-Thermal Stresses Distribution in Ambient Air-Breathing PEM Fuel Cells using Three-Dimensional CFD Model”, Recent Patents on Mechanical Engineering, Vol. 02, No. 01, pp. 26-39, 2009. https://doi.org/10.2174/2212797610902010026.

[15] Maher A. R. Sadiq Al-Baghdadi, "A CFD Analysis of Transport Phenomena and Electrochemical Reactions in a Tubular-Shaped Ambient Air-Breathing PEM Micro Fuel Cell", HKIE Transactions Hong Kong Institution of Engineers, Vol. 17, No. 02, 2010.

[16] Maher A.R. Sadiq Al-Baghdadi, "Three-dimensional computational fluid dynamics model of a tubular-shaped ambient air-breathing proton exchange membrane fuel cell", Proceedings of the Institution of Mechanical Engineers, Part A: Journal of Power and Energy, Vol. 222, No. 06, pp. 569-585, 2008. https://doi.org/10.1243/09576509JPE611.

[17] Hollebone B., "The Oil Properties Data Appendix", In Handbook of Oil Spill Science and Technology, Fingas, M., Ed. John Wiley and Sons Inc.: NY; pp 577-681, 2015.

[18] Muhannad Al-Waily, Maher A.R. Sadiq Al-Baghdadi, Rasha Hayder Al-Khayat, "Flow Velocity and Crack Angle Effect on Vibration and Flow Characterization for Pipe Induce Vibration”, International Journal of Mechanical and Mechatronics Engineering, IJMME-IJENS, Vol. 17, No. 05, pp.19-27, 2017.

[19] Muhsin J. Jweeg "Application of finite element analysis to rotating fan impellers" Doctoral Thesis, Aston University, 1983.

[20] A. R. I. Kheder, N. M. Jubeh, E. M. Tahah "Fatigue behavior of alloyed acicular ductile iron" International Journal for the Joining of Materials, Vol. 17, No. 01, pp. 7-12, 2005.

[21] Muhsin J. Jweeg, Sameer Hashim Ameen, "Experimental and theoretical investigations of dorsiflexion angle and life of an ankleFoot-Orthosis made from (Perlon-carbon fibre-acrylic) and polypropylene materials", 10th IMEKO TC15 Youth Symposium on Experimental Solid Mechanics, 2011.

[22] A. R. I. Kheder, N. M. Jubeh, E. M. Tahah, "Fatigue properties under constant stress/variable stress amplitude and coaxing effect of acicular ductile iron and $42 \mathrm{CrMo} 4$ steel", Jordan Journal of Mechanical and Industrial Engineering, Vol. 05, No. 04, 2011.

[23] Luay S. Al-Ansari, Muhannad Al-Waily, Ali M. H. Yusif, "Vibration Analysis of Hyper Composite Material Beam Utilizing Shear Deformation and Rotary Inertia Effects", International Journal of Mechanical \& Mechatronics Engineering IJMME-IJENS, Vol. 12, No. 04, 2012.

[24] Muhsin J. Jweeg, Ali S. Hammood, Muhannad Al-Waily, "Experimental and Theoretical Studies of Mechanical Properties for Reinforcement Fiber Types of Composite Materials", International Journal of Mechanical \& Mechatronics Engineering IJMME-IJENS Vol. 12, No. 04, 2012. 
[25] Muhsin J. Jweeg, Kadhim K. Resan, Mustafa Tariq Ismail, "Study of Creep-Fatigue Interaction in a Prosthetic Socket Below Knee", ASME International Mechanical Engineering Congress and Exposition, 2012.

[26] Adnan S. Jabur, Jalal M. Jalil, Ayad M. Takhakh, "Experimenta Investigation and Simulation of Al-Si Casting Microstructure Formation", Arabian Journal for Science and Engineering, Vol. 37, No. 03, pp. 777-792, 2012. https://doi.org/10.1007/s13369-012-0189-2.

[27] Muhsin J. Jweeg, Ali S. Hammood, Muhannad Al-Waily, “A Sug gested Analytical Solution of Isotropic Composite Plate with Crack Effect", International Journal of Mechanical \& Mechatronics Engineering IJMME-IJENS, Vol. 12, No. 05, 2012.

[28] Ayad M. Takhakh, Fahad M. Kadhim, Jumaa S. Chiad, "Vibration Analysis and Measurement in Knee Ankle Foot Orthosis for Both Metal and Plastic KAFO Type", ASME 2013 International Mechanical Engineering Congress and Exposition IMECE2013, November 15-21, San Diego, California, USA, 2013.

[29] Ayad M. Takhakh, Raied Z. Alfay, Abdul Rahim K. Abid Ali, "Effect of Ta addition on hardness and wear resist of $\mathrm{Cu}-\mathrm{Al}-\mathrm{Ni}$ shape memory alloy fabricated by powder metallurgy", BEIAC 2013 2013 IEEE Business Engineering and Industrial Applications Colloquium, 2013

[30] Mohsin Abdullah Al-Shammari, Muhannad Al-Waily, "Theoretica and Numerical Vibration Investigation Study of Orthotropic Hyper Composite Plate Structure", International Journal of Mechanical \& Mechatronics Engineering IJMME-IJENS, Vol. 14, No. 06, 2014.

[31] Muhsin J. Jweeg, Muhannad Al-Waily, Alaa Abdulzahra Deli, "Theoretical and Numerical Investigation of Buckling of Orthotropic Hyper Composite Plates", International Journal of Mechanical \& Mechatronics Engineering IJMME-IJENS, Vol. 15, No. 04, 2015.

[32] Muhannad Al-Waily, Zaman Abud Almalik Abud Ali, "A Suggested Analytical Solution of Powder Reinforcement Effect on Buckling Load for Isotropic Mat and Short Hyper Composite Materials Plate", International Journal of Mechanical \& Mechatronics Engineering IJMME-IJENS, Vol. 15, No. 04, 2015.

[33] Abdulkareem Abdulrazzaq Alhumdany, Muhannad Al-Waily, Mohammed Hussein Kadhim Al-Jabery, "Theoretical and Experimental Investigation of Using Date Palm Nuts Powder into Mechanical Properties and Fundamental Natural Frequencies of Hyper Composite Plate", International Journal of Mechanical \& Mechatronics Engineering IJMME-IJENS, Vol. 16, No. 01, 2016.

[34] Ahmed M. Hashim, E. K. Tanner, Jawad K. Oleiwi, "Biomechanics of Natural Fiber Green Composites as Internal Bone Plate Rafted", MATEC Web of Conferences, 2016

[35] Muhsin J. Jweeg, "A Suggested Analytical Solution for Vibration of Honeycombs Sandwich Combined Plate Structure”, International Journal of Mechanical \& Mechatronics Engineering IJMME-IJENS Vol. 16, No. 02, 2016

[36] Muhannad Al-Waily, Alaa Abdulzahra Deli, Aziz Darweesh AlMawash, Zaman Abud Almalik Abud Ali, "Effect of Natural Sisal Fiber Reinforcement on the Composite Plate Buckling Behavior", International Journal of Mechanical \& Mechatronics Engineering IJMME-IJENS, Vol. 17, No. 01, 2017.

[37] Muhsin J. Jweeg, E. Q. Hussein, K. I. Mohammed, "Effects of Cracks on the Frequency Response of a Simply Supported Pipe Conveying Fluid", International Journal of Mechanical \& Mechatronics Engineering IJMME-IJENS, Vol. 17, 05, 2017.

[38] Muhannad Al-Waily, Kadhim K. Resan, Ali Hammoudi Al-Wazir, Zaman Abud Almalik Abud Ali, "Influences of Glass and Carbon Powder Reinforcement on the Vibration Response and Characterization of an Isotropic Hyper Composite Materials Plate Structure", International Journal of Mechanical \& Mechatronics Engineering IJMME-IJENS, Vol. 17, No. 06, 2017.

[39] Mohsin Abdullah Al-Shammari, Emad Q. Hussein, Ameer Alaa Oleiwi, "Material Characterization and Stress Analysis of a Through Knee Prosthsis Sockets", International Journal of Mechanical \& Mechatronics Engineering IJMME-IJENS, Vol. 17, No. 06, 2017.

[40] Muhsin J. Jweeg, A. A. Alhumandy, H. A. Hamzah, "Material Characterization and Stress Analysis of Openings in Syme's Prosthetics", International Journal of Mechanical \& Mechatronics Engineering IJMME-IJENS, Vol. 17, No. 04, 2017.

[41] Zainab Yousif Hussien, Kadhim Kamil Resan, "Effects of Ultraviolet Radiation with and without Heat, on the Fatigue Behavior of Below-Knee Prosthetic Sockets", International Journal of Mechanical and Production Engineering Research and Development (IJMPERD), Vol. 07 , No. 06, 2017.

[42] Ameer A. Kadhim, Muhannad Al-Waily, Zaman Abud Almalik Abud Ali, Muhsin J. Jweeg, Kadhim K. Resan, "Improvement Fa- tigue Life and Strength of Isotropic Hyper Composite Materials by Reinforcement with Different Powder Materials", International Journal of Mechanical \& Mechatronics Engineering IJMME-IJENS Vol. 18, No. 02, 2018.

[43] Kadhim K. Resan, Abbas A. Alasadi, Muhannad Al-Waily, Muhsin J. Jweeg, "Influence of Temperature on Fatigue Life for Friction Stir Welding of Aluminum Alloy Materials", International Journal of Mechanical \& Mechatronics Engineering IJMME-IJENS, Vol. 18, No. 02, 2018

[44] Jawad K. Oleiwi, Ahmed Namah Hadi, "Experimental and numerical investigation of lower limb prosthetic foot made from composite polymer blends", International Journal of Mechanical and Production Engineering Research and Development, Vol. 08, No. 02, pp. 1319-1330, 2018. https://doi.org/10.24247/ijmperdapr2018151.

[45] Mahmud Rasheed Ismail, Muhannad Al-Waily, Ameer A. Kadhim, "Biomechanical Analysis and Gait Assessment for Normal and Braced Legs", International Journal of Mechanical \& Mechatronics Engineering IJMME-IJENS, Vol. 18, No. 03, 2018. 